\title{
Synthesis, antimicrobial and cytotoxicity evaluation of new cholesterol congeners
}

\author{
Mohamed Ramadan El Sayed Aly ${ }^{* 1,2, \S}$, Hosam Ali Saad ${ }^{1,3}$ \\ and Shams Hashim Abdel-Hafez ${ }^{1,4}$
}

Open Access

\author{
Full Research Paper \\ Address: \\ ${ }^{1}$ Chemistry Department, Faculty of Science, Taif University, \\ 21974-Hawyah-Taif, Kingdom of Saudi Arabia, ${ }^{2}$ Chemistry \\ Department, Faculty of Applied Science, Port Said University, \\ 42522-Port Said, Egypt, ${ }^{3}$ Chemistry Department, Faculty of Science, \\ Zagazig University, Zagazig, 44511, Egypt and ${ }^{4}$ Chemistry \\ Department, Faculty of Science, Assuit University, 71516-Assuit, \\ Egypt \\ Email: \\ Mohamed Ramadan El Sayed Aly - mrea34@hotmail.com \\ * Corresponding author \\ § Tel.: +966 (0)540731939; +20(0)100 5073049 \\ Keywords: \\ antimicrobial; chalcone; cholesterol; cytotoxicity; glycoside; triazole
}

\author{
Beilstein J. Org. Chem. 2015, 11, 1922-1932. \\ doi:10.3762/bjoc. 11.208 \\ Received: 12 June 2015 \\ Accepted: 28 September 2015 \\ Published: 16 October 2015 \\ The article is dedicated to the Institute Curie team Prof. Monneret, \\ Dr. Florent and Dr. Johannes. \\ Associate Editor: K. N. Ganesh \\ (C) 2015 Aly et al; licensee Beilstein-Institut. \\ License and terms: see end of document.
}

\begin{abstract}
$3 \beta$-Azidocholest-5-ene (3) and (3ß)-3-(prop-2-yn-1-yloxy)cholest-5-ene (10) were prepared as substrates to synthesize a variety of three-motif pharmacophoric conjugates through CuAAC. Basically, these conjugates included cholesterol and 1,2,3-triazole moieties, while the third, the pharmacophore, was either a chalcone, a lipophilic residue or a carbohydrate tag. These compounds were successfully prepared in good yields and characterized by NMR, MS and IR spectroscopic techniques. Chalcone conjugate $\mathbf{6 c}$ showed the best antimicrobial activity, while the lactoside conjugate $\mathbf{2 7}$ showed the best cytotoxic effect in vitro.
\end{abstract}

\section{Introduction}

Cholest-5-en-3 $\beta$-ol (cholesterol, 1) is an amphiphilic-like steroidal constituent of eukaryotic cell membranes. It acts as fluidity buffer and it is essential for membrane integrity and permeability. Besides, it is a substrate for the biosynthesis of steroidal hormones, bile acids and vitamin D. Pathological accumulation of oxygenated cholesterol (oxysterol) metabolites contributes to the prognosis of major chronic diseases. Cholesterol is completely absent in prokaryotic organisms [1-3].
Cholesterol gives eukaryotic membranes sufficient mechanical stiffness against cationic selective antimicrobials (CSAs) such as antimicrobial peptides (AMPs) [4] and ceragenins I (Figure 1) [5]. These CSAs selectively bind to the over expressed negatively charged peripheral phospholipids on the internal bacterial cell membranes. Following membrane association, deformation occurs causing bilayer destabilization and cell lysis [6]. According to this mechanism, synthetic polycar- 
bonates arising from organocatalytic ring-opening polymerization of cholesterol monomers were reported to create selfassemblies possessing high interior charge density and wide spectrum antimicrobial activity [6]. Interestingly, the causative vector of human gastritis and peptic ulcer Helicobacter pylori is known to elevate serum cholesterol levels in infected patients. This bacterial strain elevates the serum cholesterol levels and involves a specific enzyme known as cholesterol- $\alpha$-glucosyltransferase to glycosylate cholesterol via $\alpha$-glycosidic linkage and incorporates it into its cytoplasmic membrane. In this way it boosts resistance to host immune defense and antibiotics as well $[5,7]$.

In another case, eukaryotic cell membranes are supported by a membrane-associated cholesterol efflux regulatory protein (CERP). This protein, also known as ABCA1, is a major regulator of cellular cholesterol [8]. Synthetic BODIPY-cholesterol conjugates were reported as probes for visualization of intracellular cholesterol pools and for monitoring cholesterol efflux from cells to extracellular receptors [9]. ABCA1 plays an inevitable role in the resistance against tumorgenesis through depletion of cholesterol from cells under cancer threat, where cancer onset requires elevated intracellular cholesterol levels to build new membranes [10]. This emerging propensity of nascent cancer cells for cholesterol uptake is an attractive target to use cholesterol as vehicle to increase the bioavailability of anticancer drugs. Thus, SuberAniloHydroxamic acid-cholesterol conjugates (SAHA-cholesterol) [11], cholesterol-based charged liposomes encaging doxorubicin [12] or curcumin [13] showed higher activity compared with the native drugs. Synthetic coumarin-caged cholesterol derivatives, for instance II, were triggered to release bioactive coumarines by photolysis at $350 \mathrm{~nm}$ [14]. Dendrogenin A (DDA, III) is a natural metabolite in healthy mammals. It arises from conjugation of 5,6 $\alpha$-epoxycholesterol $(5,6 \alpha-E C)$ with histamine. In vitro studies showed that DDA induced tumor cell re-differentiation and death. This explains why it is down-regulated during carcinogenesis and opens the door for nucleophilic addition of amines to 5,6 $\alpha$-EC as a new lead for developing potential anticancer drugs [15]. Apart from antimicrobial and antiproliferative activities of cholesterol derivatives, other pharmacologic activities were reported for them. Thus, cholesterol-conjugated C-peptides, for example IV, are potent inhibitors of the Ebola virus glycoprotein-mediated cell entry [16], while cholesterol-derived amines exhibited a strong antiviral activity against the influenza A virus (IFV). These amines were able to disrupt the cholesterol-rich

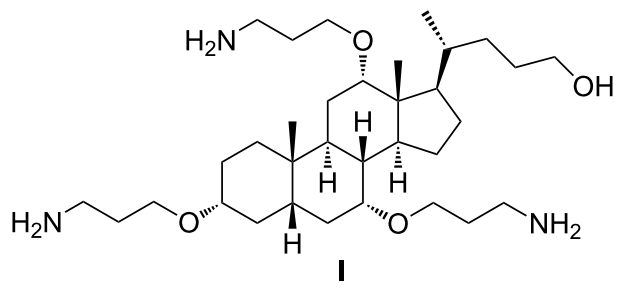<smiles>COc1cc2oc(=O)cc(COC(=O)O[C@H]3CC[C@@]4(C)C(=CC[C@@H]5[C@@H]4CC[C@]4(C)[C@@H]5CC[C@@H]4[C@H](C)CCCC(C)C)C3)c2cc1Br</smiles>

II<smiles>CC(C)CCC[C@H](C)C1CC[C@H]2[C@H]3CC(NCCc4cnc[nH]4)C4(O)C[C@H](O)CC[C@]4(C)[C@H]3CC[C@]12C</smiles><smiles>CCCCSCC(=O)O[C@H]1CC[C@@]2(C)C(=CC[C@@H]3[C@@H]2CC[C@]2(C)C([C@@H](C)CCCC(C)C)CC[C@@H]32)C1</smiles><smiles>CC(C)CCC[C@H](C)C1CCC2[C@H]3CC=C4C[C@@H](OC(=O)NCCN)CC[C@]4(C)[C@H]3CC[C@]12C</smiles><smiles></smiles>

VI

Figure 1: Structure of ceragenin (CSA-8) and selected cholesterol conjugates. 
lipid envelope and inactivate viral invasion [17]. Cholesterolbased hydrazones exhibited insecticidal activity against the larval stage of Mythimna separate (Walker) [18]. Cholesterol-carbamate conjugates, for instance (3ß)-cholest-5en-3-yl (2-aminoethyl)carbamate $(\mathbf{V})$, were used to prepare nontoxic unilamellar vesicles as nanocarriers for gene delivery into Neuro2A cells, which are involved in neurodegenerative diseases [19]. Also, the involvement of cholesterol metal ion complexes in Alzheimer's disease was reviewed [20]. Cholesterol glycosides are known for their immunostimulant activities [21]. Finally, the ability of cholesterol derivatives to selfassembly and gelation as supramolecular gels was reviewed [22]. They are beneficially applicable in materials science, reaction media, sensing and responsive materials, energy supply, biomedicine, and tissue engineering [23].

In light of this emerging propensity of cholesterol-based architectures to assimilate a plenty of pharmacological activities, cholesterol was propargylated, then reacted with azido-modified quinoline and glucopyranosyl derivatives as part of a previous study [24] to discover new antimicrobial and cytotoxic lead structures. Cholesterol conjugate VI (Figure 1) arose from this consideration to be more active than ampicillin against the Gram-negative bacterial strain Escherichia coli (ATCC 11775) and the Gram-positive bacterial strain Staphylococcus aureus (ATTC 12600), while its antifungal activities against the filamentous fungal strain Aspergillus flavus (Link) and the yeast forming fungal strain Candida albicans (ATCC 7102) were moderate compared with amphotericin B in vitro. In the cytotoxicity study, this derivative was the most cytotoxic one against the prostate cancer PC 3 cell line but it was 2.3 fold less active than doxorubicin in vitro. Therefore, this article describes the synthesis of analogues of VI with different lipid, glycon and chalcone $[25,26]$ tags to assay and evaluate their in vitro antimicrobial and cytotoxic activities against the above mentioned microbial organisms and the prostate cancer PC3 cell line. It is worth mentioning that the bacterial $[27,28]$ and fungal $[29,30]$ strains in this consideration were elected as they represent the main microbial classes for our in vitro antimicrobial evaluation. On the other hand, prostate cancer was considered because it is highly prevalent malignancy and on the second place in the list of cancer-related deaths due to its high metastatic potential [31].

\section{Results and Discussion Chemistry}

Cholest-5-en-3 $\beta$-ol (1) was activated as bromide in very good yield under Appel conditions [32], which means treatment with $\mathrm{CBr}_{4} / \mathrm{PPh}_{3}$ to afford $3 \alpha$-bromocholest-5-ene 2 due to inversion of the configuration at the $\mathrm{C}-3$ carbon (Scheme 1). The $\mathrm{O}-\mathrm{H}_{\text {str }}$ band of 1 disappeared upon this step. An $\mathrm{S}_{\mathrm{N}} 2$ substitution of the bromine atom of compound 2 with the $\mathrm{N}_{3}$ group was ensued by refluxing with $\mathrm{NaN}_{3}$ in dry DMF to afford $3 \beta$-azidocholest-5ene (3) after inversion of the configuration again at the C-3 carbon. The product could be isolated in good yield and the IR spectrum showed the $\mathrm{N}_{3}$ stretching as medium band at $2081 \mathrm{~cm}^{-1}$. Other methods for related syntheses were reported in $[33,34]$.

The target cholesterol-chalcone conjugates $\mathbf{6 a - c}$ and $\mathbf{7 a , b}$ were prepared by reacting $3 \beta$-azidocholest-5-ene (3) with propargylated chalcones $\mathbf{4 a - c}$ and $\mathbf{5 a}, \mathbf{b}$ [24] under CuAAC conditions [35]. The reactions proceeded fairly in gently refluxing THF/ $\mathrm{H}_{2} \mathrm{O}$ mixture containing L-ascorbic acid as reducing agent and a catalytic amount of $\mathrm{CuSO}_{4} \cdot 5 \mathrm{H}_{2} \mathrm{O}$.

The ${ }^{13} \mathrm{C}$ NMR spectra of this series showed the $\mathrm{C}=\mathrm{O}$ signal at $\delta$ values within the range of $187-188 \mathrm{ppm}$, while the ${ }^{1} \mathrm{H}$ NMR spectra showed the trans configuration of the enone moiety due to the high coupling constant of $J_{\alpha, \beta} 15.6 \mathrm{~Hz}$, with the $\beta$-proton being more deshielded than the $\alpha$-proton. The $\mathrm{OCH}_{2}$ signal was clearly observed in all derivatives at $\delta \approx 5.30 \mathrm{ppm}$. On the other hand, the olefinic H-6 of cholesterol was observed at $\delta \approx 5.40 \mathrm{ppm}$. The ${ }^{1} \mathrm{H}$ NMR spectra of these compounds also showed the $\mathrm{CH}_{3}-25$ and $\mathrm{CH}_{3}-26$ signals of cholesterol as doublets at $\delta \approx 0.86$ and $0.87 \mathrm{ppm}$ with a coupling constant of $J=3.0 \mathrm{~Hz}$. The $\mathrm{CH}_{3}-21$ was observed as doublet nearby the previous signals, while the $\mathrm{CH}_{3}-18$ singlet was the most shielded at $\delta \approx 0.85 \mathrm{ppm}$ in all spectra. These five ${ }^{1} \mathrm{H}$ NMR signals seemed to be a NMR identity fingerprint region of cholesterol. All these spectral data, besides the recorded mass peaks at $m / z$ values corresponding to the exact molecular weight of each derivative supported these azide-alkyne cycloadditions.

The second set of cholesterol conjugates (Scheme 2 and Scheme 3) was prepared by CuAAC of (3ß)-3-(prop-2-yn-1yloxy)cholest-5-ene (10) with azidoalcanols 9a,b [24] and $3 \beta$-azidocholest-5-ene (3). These investigations aimed to address whether the terminal surface recognition glycon tag was necessary to stimulate the biological activity of triazolocholesterol [24] or just an alternative unique $\mathrm{OH}$ group, as in conjugates 11a,b, or even without it as in derivatives 12 and 13, can retain its activity. Particularly, hydroxyalkyl-1,2,3-triazoles were reported as valuable pharmacophores [36].

The products were isolated in good yields and the H-5 signal of triazole ( ${ }^{1} \mathrm{H}$ NMR) could be observed as a singlet at $\delta \approx 7.5 \mathrm{ppm}$. Compound 11a was further converted into the corresponding bromo derivative $\mathbf{1 2}$ in good yield under the same conditions used to prepare compound 2 . This step aimed to have an alkylating probe that might target nucleic acids or proteins in the tested biological systems. 

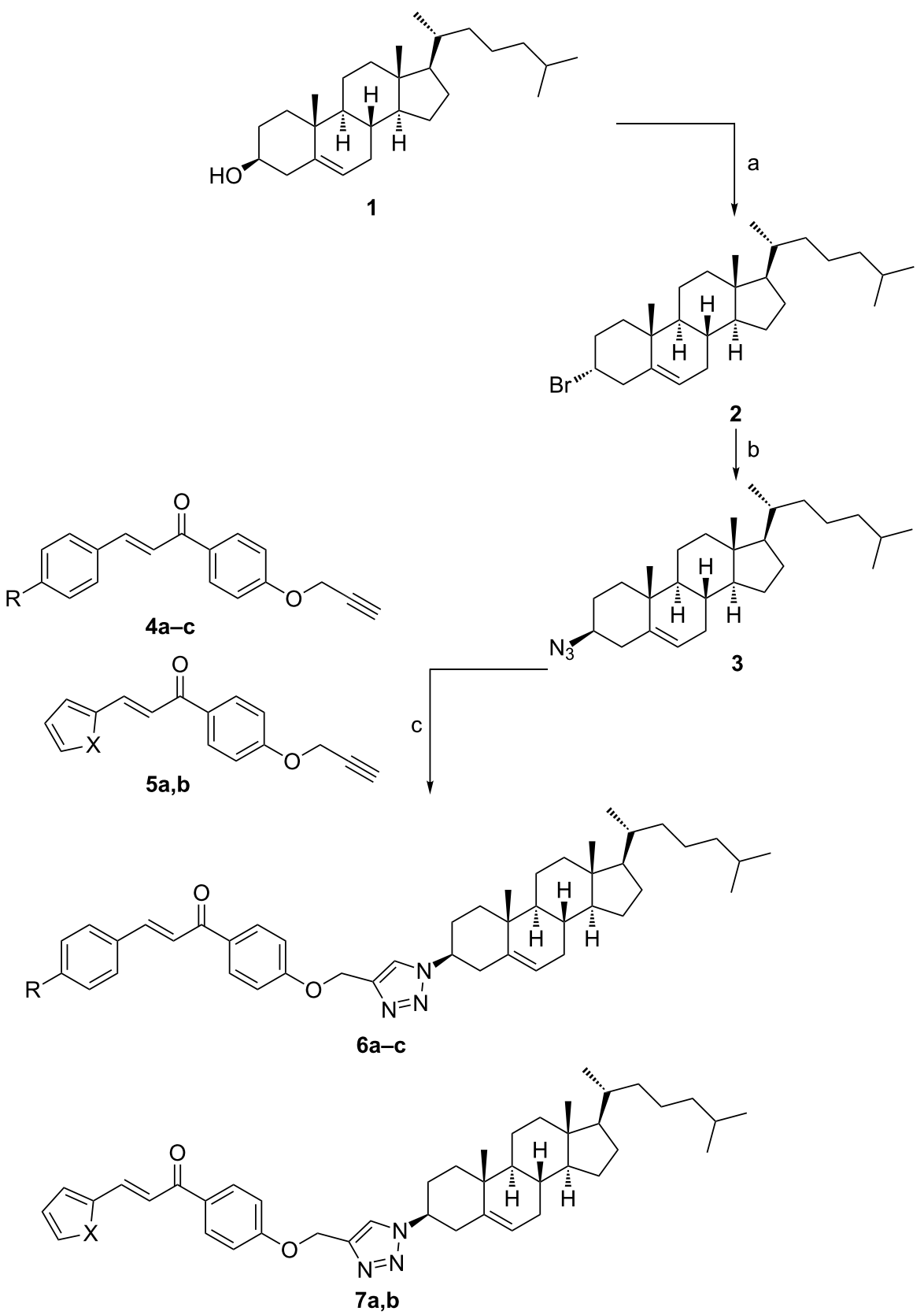

Scheme 1: Reagents and conditions: (a) $\mathrm{CBr}_{4}, \mathrm{PPh}_{3}$, DCM (74\%); (b) $\mathrm{NaN}_{3}, \mathrm{DMF}, 100{ }^{\circ} \mathrm{C}(63 \%)$; (c) $\mathrm{CuSO}_{4} \cdot 5 \mathrm{H}_{2} \mathrm{O}$, L-ascorbic acid (L-AsAc), THF/ $\mathrm{H}_{2} \mathrm{O}\left[\mathbf{6 a}, \mathrm{R}=\mathrm{H}(40 \%) ; \mathbf{6 b}, \mathrm{R}=\mathrm{OMe}(41 \%) ; \mathbf{6 c}, \mathrm{R}=\mathrm{NMe}_{2}(68 \%) ; \mathbf{7 a}, \mathrm{X}=\mathrm{O}(47 \%) ; \mathbf{7 b}, \mathrm{X}=\mathrm{S}(60 \%)\right]$

The 1,2,3-triazole-bridged bicholesterol 13 (Scheme 3) was prepared in excellent yield. The H-5 signal of triazole $\left({ }^{1} \mathrm{H}\right.$ NMR) also was observed as singlet at $\delta=7.78 \mathrm{ppm}$ confirming the cycloaddition of derivatives $\mathbf{3}$ and $\mathbf{1 0}$.

D-Glucosamine is an essential constituent of many naturally occurring oligosaccharides such as bacterial and fungal cell walls. Mainly, it is available as $N$-acetylglucosamine in $\beta$-glycosidic linkages ( $\beta$-D-GlcNAc) [37]. Chitinases are special enzymes involved in processing this valuable metabolite. Therefore, triazolocholesterol-glucopyranosylamine conjugates 16, 17 and 20 (Scheme 4) were prepared to compare the pharmacological effects of the modification of the D-glucopyranose moiety in VI (Figure 1) as glucosamine in different forms and with a hexyl spacer. Retaining the dimethylmaleoyl (DMM) group in targets $\mathbf{1 6}$ and $\mathbf{2 0}$ was based on the finding that NDMM-protected phosphatidylcholine showed better antiproliferative activity than its natural hydrochloride congener [38]. 


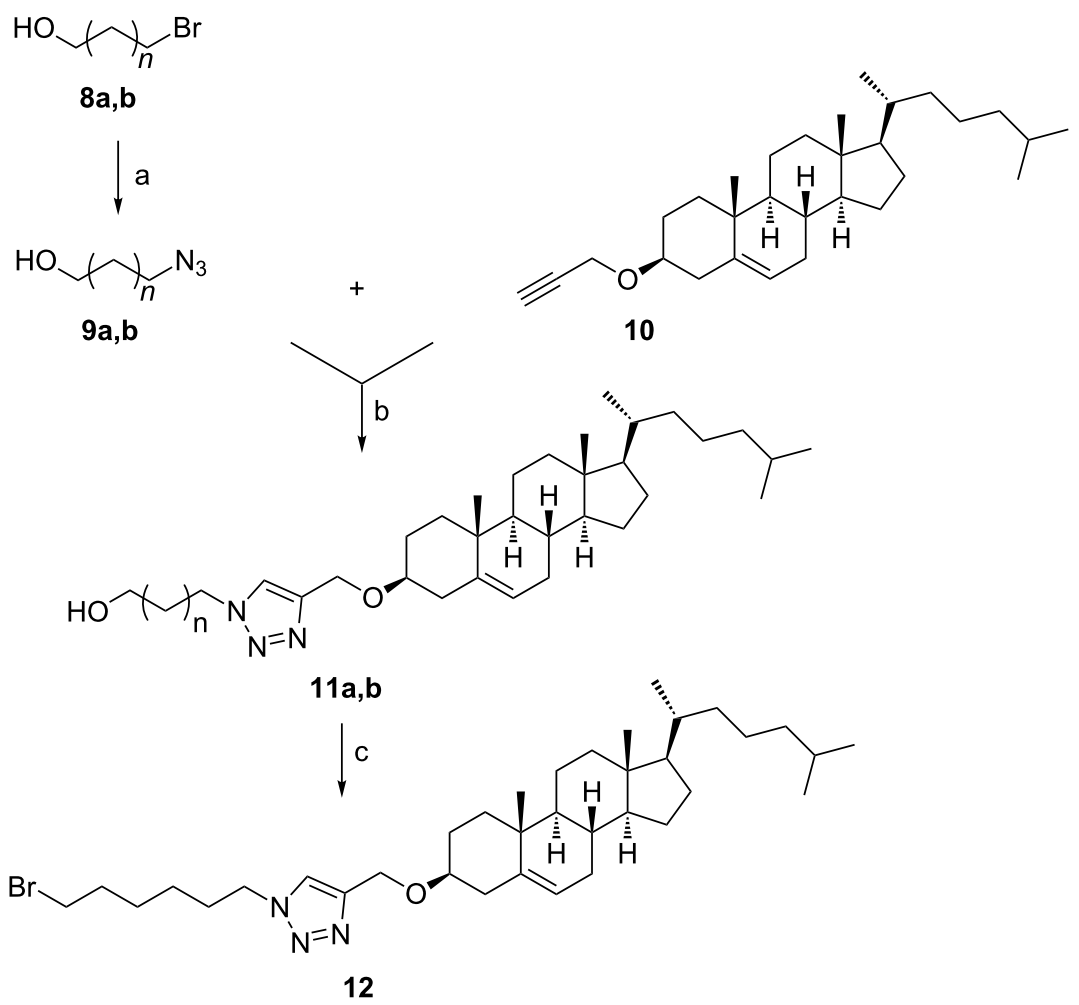

Scheme 2: Reagents and conditions: (a) $\mathrm{NaN}_{3}$, DMF, $100{ }^{\circ} \mathrm{C}(9 \mathrm{~b}, 47 \%)$; (b) $\mathrm{CuSO}_{4} \cdot 5 \mathrm{H}_{2} \mathrm{O}, \mathrm{L}-\mathrm{AsAc}, \mathrm{THF} / \mathrm{H}_{2} \mathrm{O}[11 \mathrm{a}, n=4(90 \%) ; 11 \mathrm{~b}, n=9(67 \%)]$; (c) $\mathrm{CBr}_{4}, \mathrm{PPh}_{3}, \mathrm{DCM}(59 \%)$.

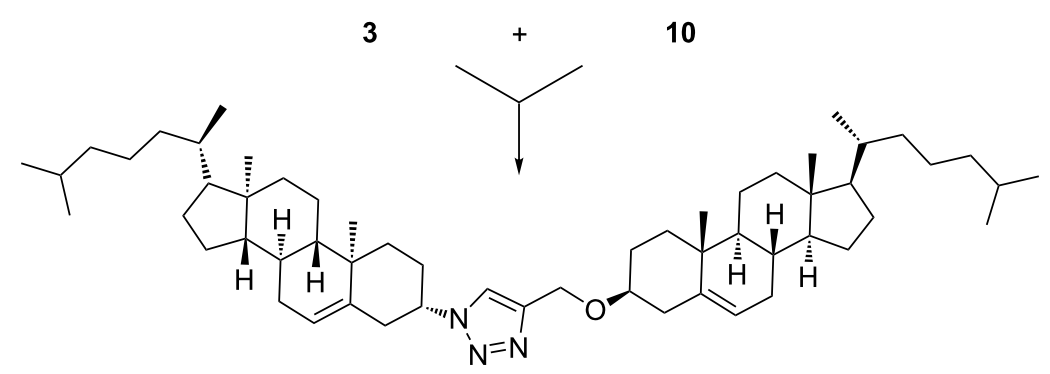

13

Scheme 3: Reagents and conditions: $\mathrm{CuSO}_{4} \cdot 5 \mathrm{H}_{2} \mathrm{O}, \mathrm{L}-\mathrm{AsAc}, \mathrm{THF} / \mathrm{H}_{2} \mathrm{O}(96 \%)$.

Thus, to prepare these targets glucosyl donor 14 [39] was coupled with cholest-5-en-3 $\beta$-ol (1) as glycosyl acceptor in the presence of catalytic TMSOTf as promoter to afford 15 in 74\% yield. The large anomeric coupling constant $\left(J_{1,2}=8.4 \mathrm{~Hz}\right)$ of the pyranoside moiety at $\delta=5.30 \mathrm{ppm}$ ensured the $\beta$-configuration of this glycoside.

Deacetylation of intermediate $\mathbf{1 5}$ under Zémplen conditions, i.e., catalytic $\mathrm{NaOMe}$ in $\mathrm{MeOH}$ [40], safely afforded the target conjugate 16 in $84 \%$ yield without affecting the DMM group. Despite, the two $\mathrm{C}=\mathrm{O}$ groups could not be seen with certain at $\delta \approx 174.00 \mathrm{ppm}\left({ }^{13} \mathrm{C} \mathrm{NMR}\right)$, the two maleimide $\mathrm{CH}_{3}$ groups were observed at $\delta=8.80 \mathrm{ppm}$ as a proof of structure.

Substitution of the DMM group with an acetyl group was performed under standard conditions, i.e., treatment with $\mathrm{NaOH}$ for ring opening [39], $\mathrm{HCl}$ at $\mathrm{pH} 5$ for amide cleavage, peracetylation and then $O$-deacetylation. Under these condi- 


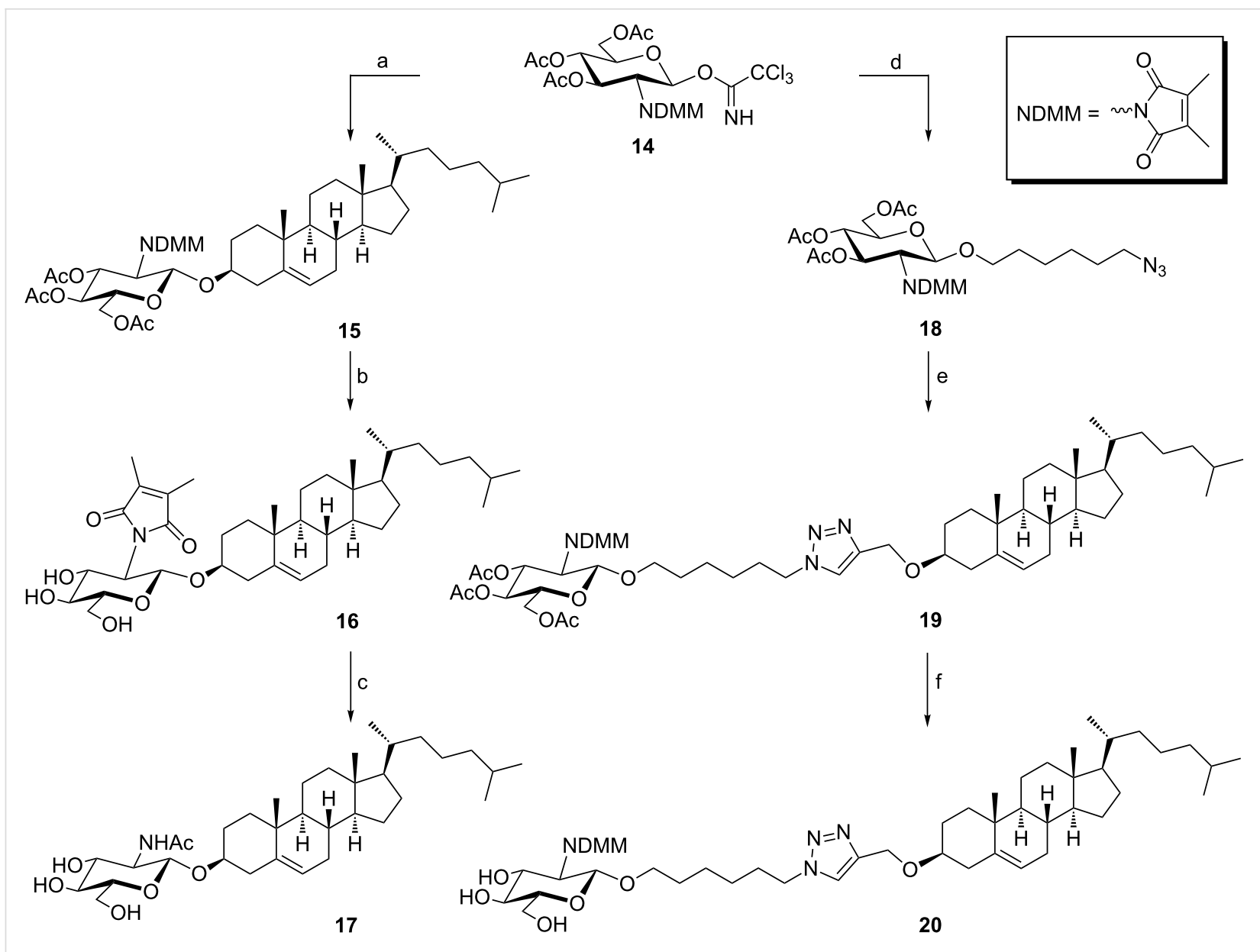

Scheme 4: Reagents and conditions: (a) 1, TMSOTF, $\mathrm{CH}_{3} \mathrm{CN}$, rt (74\%); (b) $\mathrm{NaOMe}, \mathrm{MeOH}$ (84\%); (c) NaOH; $\mathrm{HCl}$ (pH 5); $\mathrm{Ac} 2 \mathrm{O} / \mathrm{Pyr} ; \mathrm{NaOMe} / \mathrm{MeOH}$ (37\%); (d) 9a, TMSOTf, DCM (71\%); (e) 10, $\mathrm{CuSO}_{4} \cdot 5 \mathrm{H}_{2} \mathrm{O}$, L-AsAc, THF/H $\mathrm{H}_{2} \mathrm{O}(67 \%)$; (f) $\mathrm{NaOMe}, \mathrm{MeOH}(75 \%)$.

tions, compound 17 was prepared in $37 \%$ yield. The $\mathrm{C}=\mathrm{O}$ signal $\left({ }^{13} \mathrm{C} \mathrm{NMR}\right)$ was observed at $\delta=183.10 \mathrm{ppm}$ with concurrent disappearance of the maleimide $\mathrm{CH}_{3}$ signal. A peak was observed at $\mathrm{m} / \mathrm{z}$ value corresponding to the exact molecular mass.

Conjugate 20 was prepared under similar conditions as employed for the synthesis of compound 17. Thus, coupling of azidohexanol 9a with trichloroacetimidate 14 afforded the intermediate $\beta$-glycoside $\mathbf{1 8}\left(J_{1,2}=8.4 \mathrm{~Hz}\right.$ at $\left.\delta=5.18 \mathrm{ppm}\right)$ in $71 \%$ yield. CuAAC of derivative $\mathbf{1 8}$ with compound $\mathbf{1 0}$ afforded compound 19 in $67 \%$ yield. The H-5 proton of the triazole moeity was observed at $\delta=7.49 \mathrm{ppm}$ which confirms a successful cycloaddition step. Deacetylation of $\mathbf{1 9}$ afforded target spacer linked conjugate $\mathbf{2 0}$ in $75 \%$ yield. Unlike compound 16, the two $\mathrm{C}=\mathrm{O}{ }^{13} \mathrm{C}$ NMR signals of conjugate 20 were clearly observed at $\delta=174.28 \mathrm{ppm}$.

Then, attention was given to prepare conjugate $\mathbf{2 4}$ (Scheme 5). This is to investigate the pharmacological effects of the maltose tag compared with glucose as previously investigated in the case of VI [24]. Thus, coupling of glycosyl donor 21 [41] with acceptor 9a afforded maltoside $\mathbf{2 2}$ in low yield (Scheme 5). CuAAC of substrate 22 with 10 yielded derivative $\mathbf{2 3}$ in $62 \%$ yield. The ${ }^{1} \mathrm{H}$ NMR showed that the $\mathrm{B}$ ring of the maltose moiety was $\alpha$-configurated at the glycosidic center $\left(\mathrm{H}-1_{\mathrm{B}}\right.$ at $\delta=5.40 \mathrm{ppm}, J_{1,2}=4.2 \mathrm{~Hz}$ (see Scheme 5 compound 21 for the assignment of rings $\mathrm{A}$ and $\mathrm{B}$ of the maltose moiety) and the $\mathrm{A}$ ring $\beta$-configurated $\left(\mathrm{H}-1_{\mathrm{A}}\right.$ at $\left.\delta=4.49 \mathrm{ppm}, J_{1,2}=7.8 \mathrm{~Hz}\right)$. The traizole $\mathrm{H}-5$ was observed as singlet at $\delta=7.52 \mathrm{ppm}$, while the cholesterol $\mathrm{CH}_{3}$ groups fingerprint signals were observed in the upfield region of the spectrum.

Deacetylation of compound $\mathbf{2 3}$ smoothly afforded the target conjugate $\mathbf{2 4}$ in $78 \%$ yield. Finally, compound $\mathbf{2 8}$ (Scheme 6) was attempted to be prepared to investigate the cytotoxicity of a lactose scaffold with a cholesterol moiety at the C-3 carbon of the $\mathrm{B}$ ring of the lactose. This is because chemically modified $3 \beta$-lactosides were emerged as potential galectin- 3 inhibitors. Galectin-3 is a member of the protein family known as galectins 


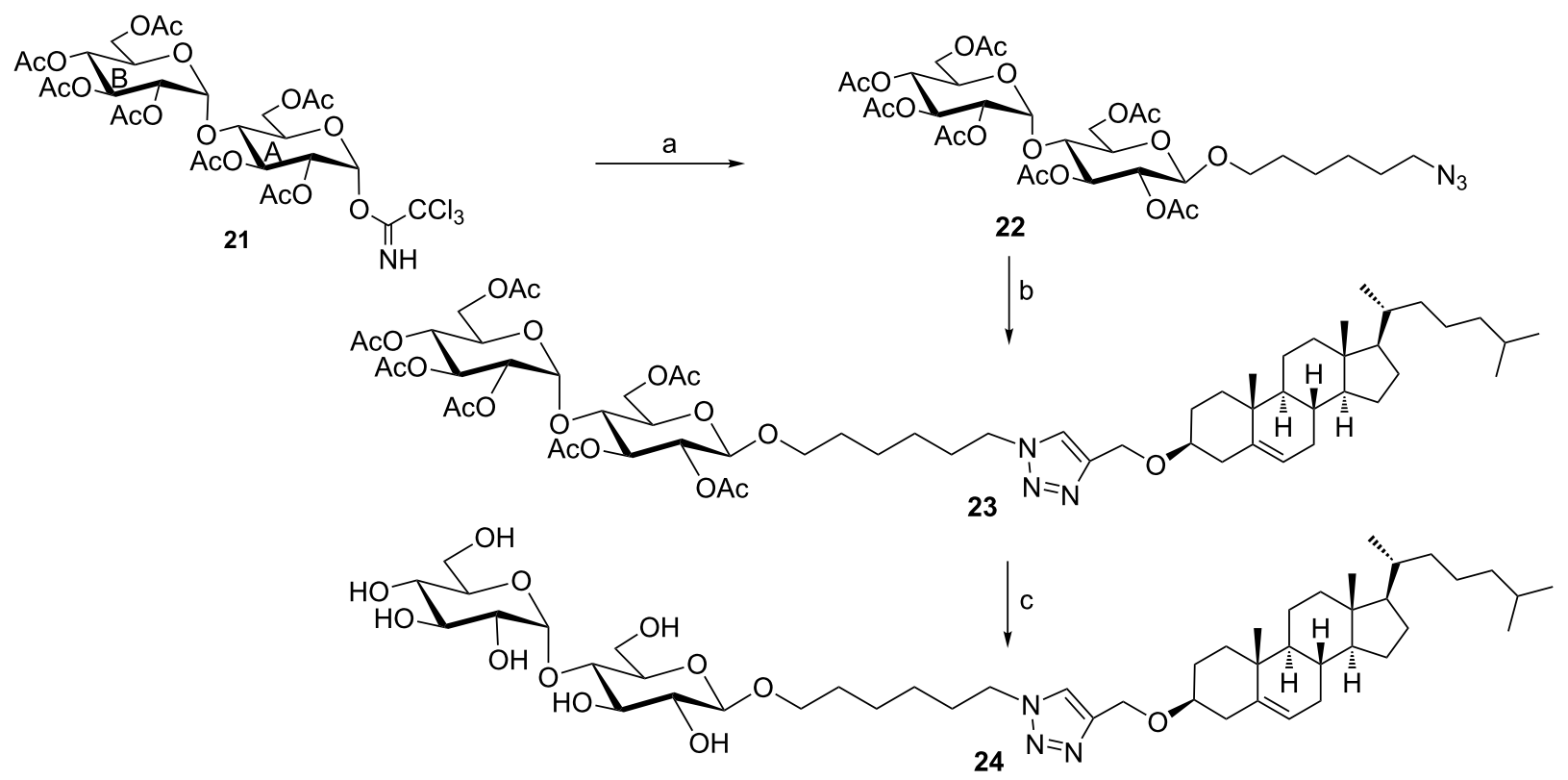

Scheme 5: Reagents and conditions: (a) 9a, TMSOTF, DCM, rt (19\%); (b) 10, $\mathrm{CuSO}_{4} \cdot 5 \mathrm{H}_{2} \mathrm{O}, \mathrm{L}-\mathrm{AsAc}, \mathrm{THF} / \mathrm{H}_{2} \mathrm{O}(62 \%)$; (c) $\mathrm{NaOMe} / \mathrm{MeOH}(78 \%)$. $A:$ Ring $A$ of the maltose moiety, $B$ : Ring B of the maltose moiety.

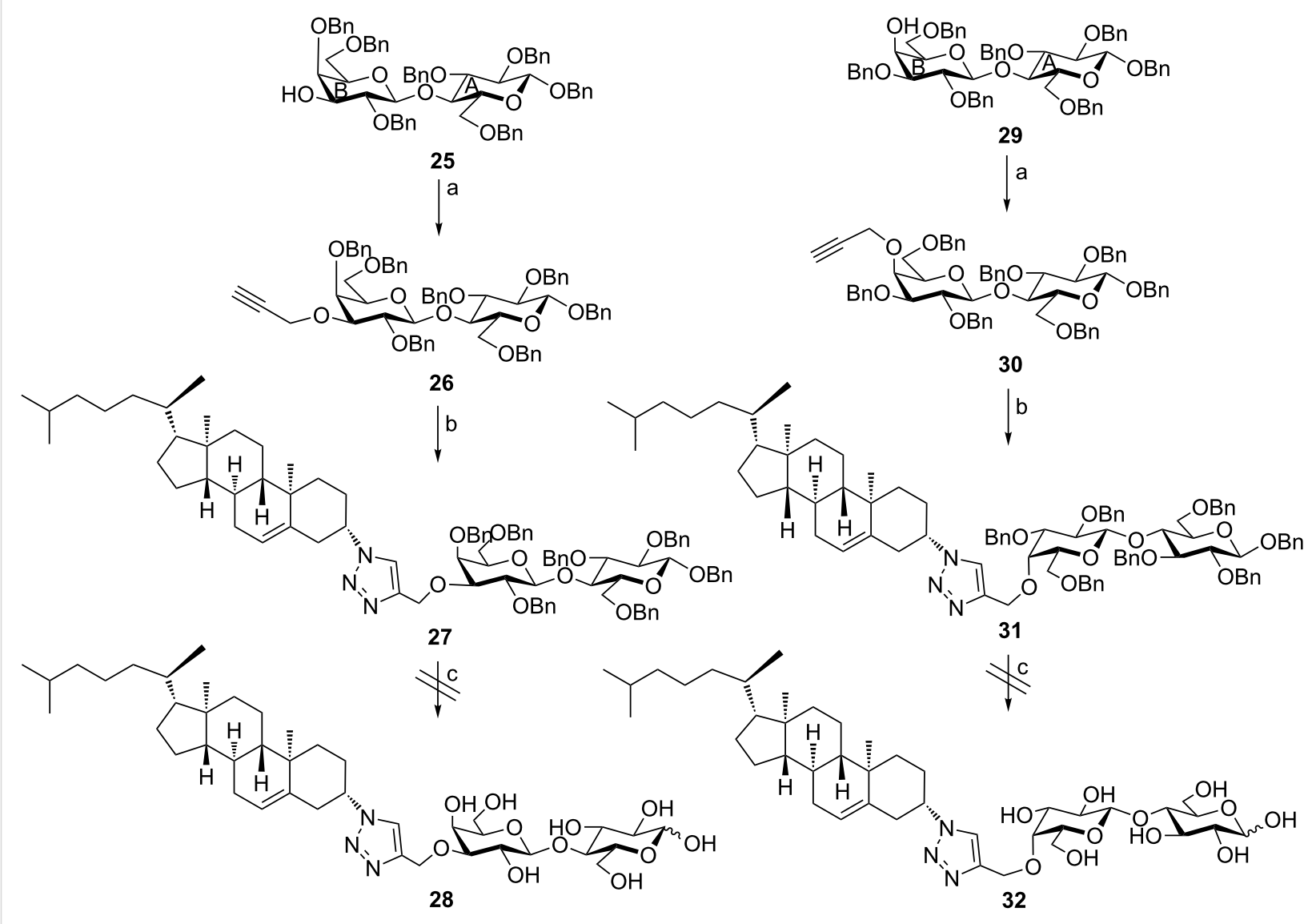

Scheme 6: Reagents \& conditions: (a) Propargyl bromide, NaH, Et $2 \mathrm{O} / \mathrm{DMF}$ (quant. for both 26 and 30); (b) 3, $\mathrm{CuSO}_{4} \cdot 5 \mathrm{H}_{2} \mathrm{O}, \mathrm{L}-\mathrm{AsAc}, \mathrm{THF} / \mathrm{H}_{2} \mathrm{O}(89 \%$ for 27 and $74 \%$ for 31); (c) $\mathrm{H}_{2}, \mathrm{Pd} / \mathrm{C} 10 \%$, MeOH. A: Ring A of the lactose moiety, B: Ring B of the lactose moiety. 
and this subfamily is believed to be involved in tumorigenesis $[42,43]$. To this endeavor, $3 \beta-O$-propargylated lactose derivative $\mathbf{2 6}$ was reacted with compound $\mathbf{3}$ to afford intermediate triazole bridged conjugate $\mathbf{2 7}$ in $89 \%$ yield. This intermediate was attempted to be debenzylated by treatment with $\mathrm{H}_{2}$ and $\mathrm{Pd} / \mathrm{C} 10 \%$ but the benzyl groups could not be removed under these conditions.

For comparison reasons, derivative 31, that has the cholesterol moiety at the C-4 carbon of the B ring of the lactose moiety, was prepared by $\mathrm{CuAAC}$ of substrate $\mathbf{3 0}$ with $\mathbf{3}$ to afford intermediate 31 in $74 \%$ yield. This intermediate resisted reductive debenzylation under the same conditions and compound $\mathbf{3 2}$ also could not be obtained $[44,45]$.

To investigate, whether the triazole or the cholesterol entities are not compatible with these debenzylation conditions, probes 36 and $\mathbf{3 8}$ (Scheme 7) were prepared by $\mathrm{CuAAC}$ of derivative 34 with compounds $\mathbf{3 5}$ and $\mathbf{9 b}$, respectively [24].
Both conjugates were prepared in very good yields. Probe 38 was acetylated to confirm the regioselectivity at the C-4 position of the lactose B ring [46].

The ${ }^{1} \mathrm{H}$ NMR of compound 39, thus, showed the H-4 proton of the lactose $\mathrm{B}$ ring discriminated at $\delta=5.46 \mathrm{ppm}$ with a very small coupling constant due to a weak equatorial-diaxial coupling. Compounds $\mathbf{3 6}$ and $\mathbf{3 8}$ were subjected to reductive debenzylation. While, compound $\mathbf{3 8}$ could be debenzylated in excellent yield, quinoline derivative $\mathbf{3 6}$ could not be debenzylated even in the presence of $\mathrm{Pd}(\mathrm{OH})_{2}$.

Consequently, it might be concluded that bulky substituents such as cholesterol and quinoline hindered the complete reductive debenzylation, at least under the described conditions.

\section{Biology}

The antibacterial activity of selected newly synthesized cholesterol conjugates was evaluated in vitro against E.coli (ATCC

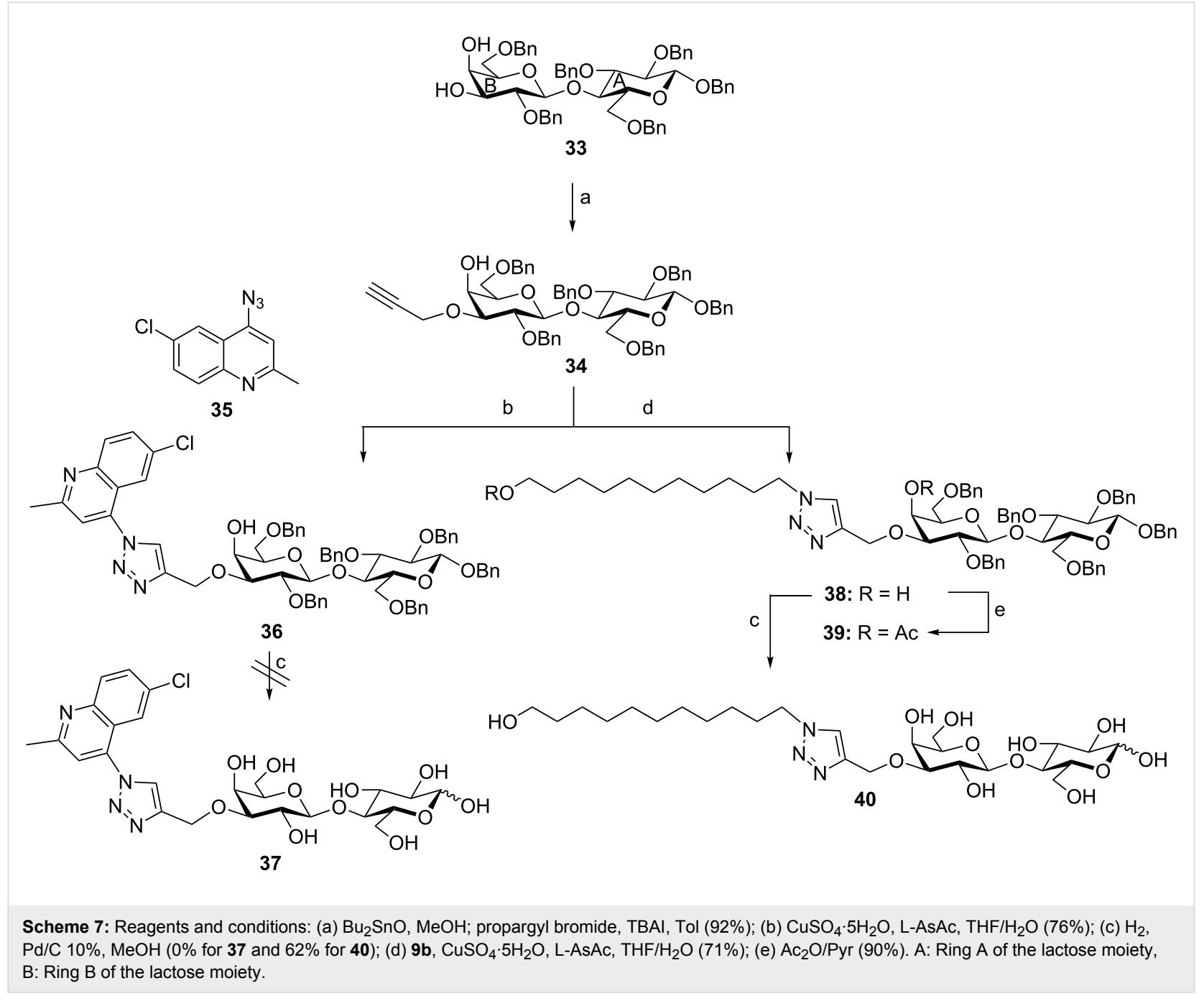


11775 ) and S. aureus (ATTC 12600) according to the Kirby-Bauer disc diffusion method (Figure 2) [47].

The results shown in Figure 2 revealed that the chalcone modified cholesterol derivatives $\mathbf{6 a}, \mathbf{c}$ and $\mathbf{7 b}$ were the most potent derivatives against $E$. coli. They were as active as ampicillin and insignificantly varied with each other. Thus, the chalcones possessing unsubstituted phenyl, and $p$-dimethylaminophenyl as well as 2-thienyl alternatives were more active than other congeners against $E$. coli. Despite, derivatives $\mathbf{6 b}, \mathbf{7 a}, \mathbf{1 1 b}, \mathbf{1 2}$, 13, 17, 20 and 24 varied significantly with the control, they insignificantly varied with each other and they were 37-64\% less active than ampicillin. Compound 11a, that is modified with a $\mathrm{C} 11$ lipid tail, was the least active cholesterol derivative, thus, it was $73 \%$ less active than the control.

On the other hand, derivatives $\mathbf{6 c}, \mathbf{7 b}$ and the bicholesterol $\mathbf{1 3}$ were the most active cholesterols against $S$. aureus. All these derivatives insignificantly varied with the control (ampicillin). All other derivatives varied significantly with the control without significant variation among each other. They were $28-56 \%$ less active than the control. Therefore, cholesterol-chalcone conjugation could afford derivatives that were as active as ampicillin. However, conjugate VI from the previous investigation was still more active than these conjugates [24].

The antifungal activity of selected newly synthesized chalcone conjugates was evaluated in vitro against $A$. flavus (Link) and Candida albicans (ATCC 7102) similarly according to the Kirby-Bauer disc diffusion method (Figure 2).

Although, the series was inactive against $A$. flavus, they showed some promising antifungal results against $C$. albicans. As shown in Figure 2, only chalcone $\mathbf{6 c}$ was as active as the control (amphotericin B). Cholesterols 6a,b, 7a,b, 11b, 13 and 20 significantly varied with the control and they were by $50-71 \%$ less active, while the cholesterol derivatives 11a, 12, 17 and 24 were entirely inactive.

Therefore, clicked cholesterol-chalcone conjugates could afford, at least, one derivative of promising anticandidal activity which was even better than VI.

A group of target cholesterols were screened in vitro as cytotoxic agents against the human prostate cancer cell line PC3

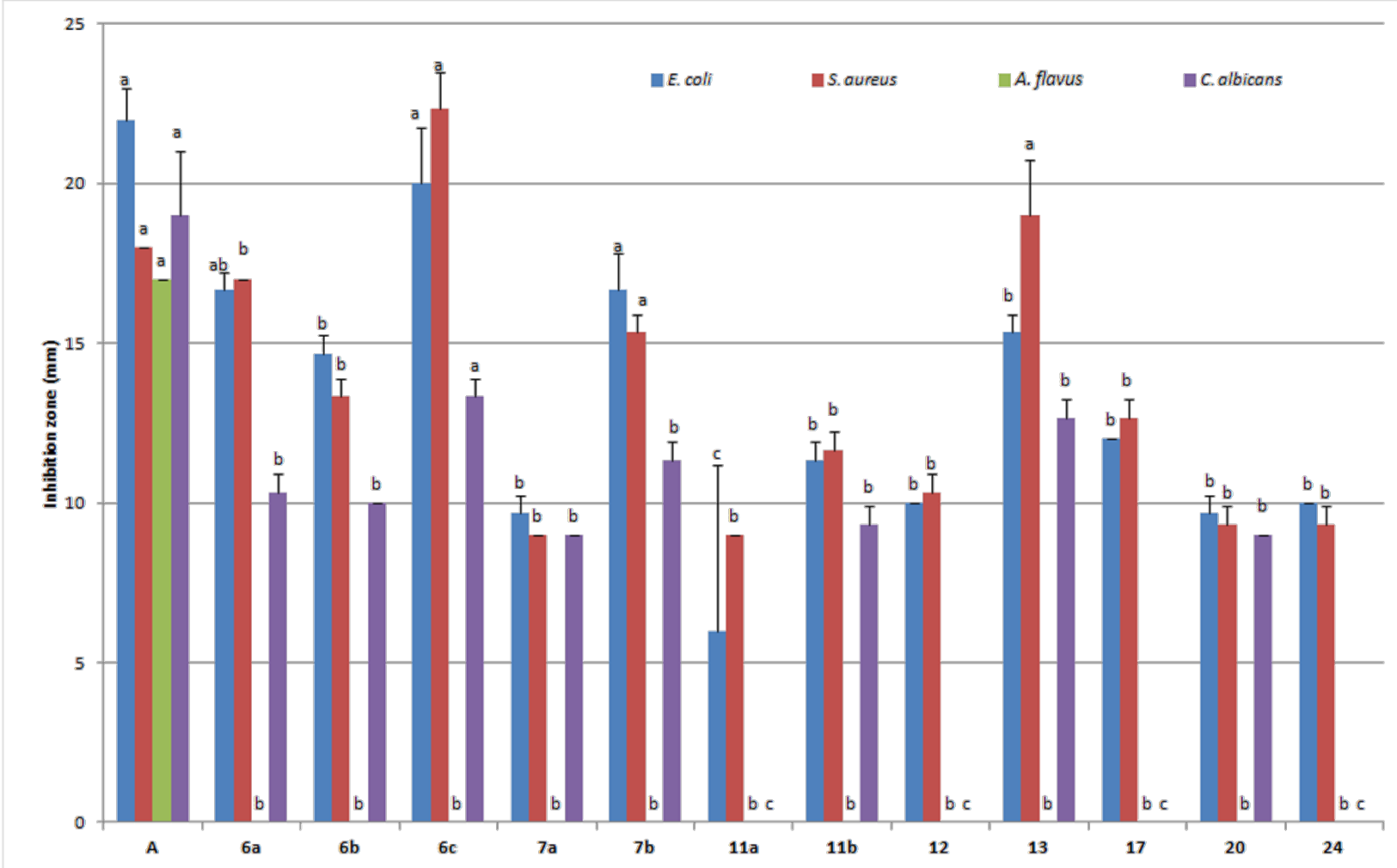

Figure 2: In vitro antimicrobial activity of some new cholesterol derivatives against E.coli, S. aureus. A. flavus and C. albicans. Ampicillin was used as positive control $(\mathbf{A})$ in the case of $E$. coil and $S$. aureus, while, amphotericin B was used in the case of $A$. flavus and $C$. albicans. Different letters on the column for each parameter varied significantly at $p \leq 0.05$. These characters $(\mathrm{a}, \mathrm{b}$, etc) above the columns denote to statistical variances. Two or more columns with different vertical values but specified with the same character mean that their variation is not significant, i.e., they are equally active. 
using the sulforhodamine B colorimetric (SRB) assay and doxorubicin as positive control $\left(\mathrm{IC}_{50}=8.8 \mu \mathrm{M}\right)$ (Figure 3) [48].

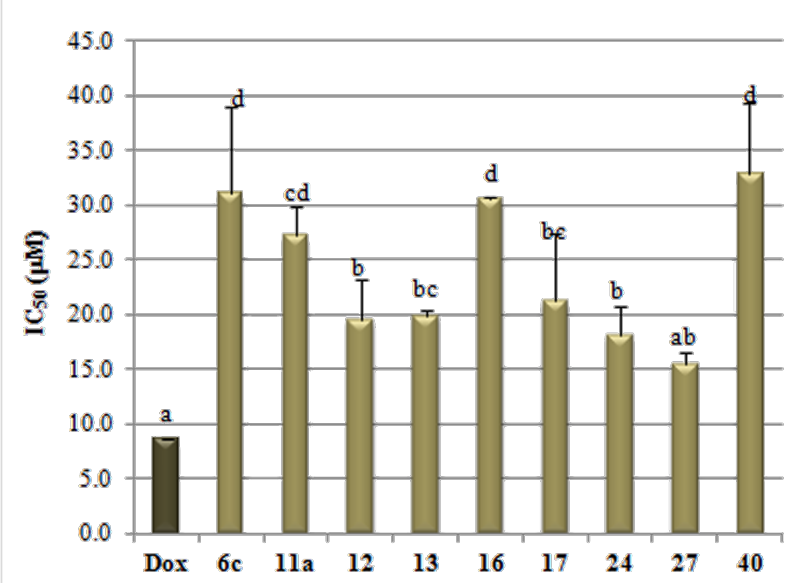

Figure 3: Cytotoxicity effect of some new cholesterol derivatives on the PC3 cell line. Doxorubicin (Dox) was used as positive control. Different letters on the column varied significantly at $p \leq 0.05$.

As shown in Figure 3, cholesterol-lactoside conjugate 27 afforded the best cytotoxicity among this series of compounds without significant variation with the control. While, its analogue hydroxyundecyl analogue $\mathbf{4 0}$ was the least cytotoxic conjugate $\left(\mathrm{IC}_{50}=33.5 \mu \mathrm{M}\right)$. Thus, this variation showed a potential cytotoxic effect for a cholesterol residue attached to the carbon $\mathrm{C}-3$ of the $\mathrm{B}$ ring of the lactose scaffold. On the other hand, modified cholesterols with a chalcone residue (6c), a hydroxyhexyl arm (11a), and NDMM protected glucosamine tag (16) showed low cytotoxicity as triazole 40. These conjugates showed $\mathrm{IC}_{50}$ values of $31.2,27.1$ and $30.3 \mu \mathrm{M}$, respectively and they varied insignificantly with each other. Finally, modified cholesterols with a bromohexyl arm (12), a GlcNAc residue (17), a maltoside tag (24) and even the triazole bridged bicholesterol (13) showed medium cytotoxic effects within the range of $18.3-21.5 \mu \mathrm{M}$ and they varied insignificantly with each other.

\section{Conclusion}

In conclusion, cholesterol was successfully converted into $3 \beta$-azidocholest-5-ene (3) in good yield. This key intermediate, besides $3 \beta$-(prop-2-yn-1-yloxy)cholest-5-ene (10) were involved in a series of CuAAC reactions to afford a set of new modified cholesterols. The chalcone-triazole-cholesterol derivative $\mathbf{6 c}$ emerged as the most promising antimicrobial probe in this study. It was as active as the controls against $E$. coli, S. aureus and C. albicans. The cholesterol-triazole-lactoside congener $\mathbf{2 7}$ displayed the best in vitro cyctotoxic effect against the prostate cancer PC3 cell line and it showed an activity close to that of the positive control doxorubicin.

\section{Supporting Information}

\section{Supporting Information File 1}

Experimental section.

[http://www.beilstein-journals.org/bjoc/content/

supplementary/1860-5397-11-208-S1.pdf]

\section{Acknowledgements}

The financial support of Port Said and Taif Universities, Grant Number 1-435-3248 are gratefully acknowledged. The valuable discussions with Prof. R. R. Schmidt at Konstanz University, Germany are kindly acknowledged too.

\section{References}

1. Hanukoglu, L. J. Steroid Biochem. Mol. Biol. 1992, 43, 779-804. doi:10.1016/0960-0760(92)90307-5

2. Poli, G.; Biasi, F.; Leonarduzzi, G. Redox Biol. 2013, 1, 125-130. doi:10.1016/j.redox.2012.12.001

3. Wennberg, C. L.; van der Spoel, D.; Hub, J. S. J. Am. Chem. Soc. 2012, 134, 5351-5361. doi:10.1021/ja211929h

4. Bender, J. R.; McHenry, A. J.; Ramamoorthy, A. Front. Immunol. 2012, 3, 1-4.

5. Trainor, E. A.; Horton, K. E.; Savage, P. B.; Testerman, T. L.; McGee, D. J. Infect. Immun. 2011, 79, 88-97. doi:10.1128/IAI.00974-09

6. Coady, D. J.; Ong, Z. Y.; Lee, P. S.; Venkataraman, S.; Chin, W.; Engler, A.; Yang, Y. Y.; Hedrick, J. L. Adv. Healthcare Mater. 2014, 3, 882-889. doi:10.1002/adhm.201300554

7. McGee, D. J.; George, A. E.; Trainor, E. A.; Horton, K. E.; Hildebrandt, E.; Testerman, T. L. Antimicrob. Agents Chemother. 2011, 55, 2897-2904. doi:10.1128/AAC.00016-11

8. Luciani, M. F.; Denizot, F.; Savary, S.; Mattei, M. G.; Chimini, G. Genomics 1994, 21, 150-159. doi:10.1006/geno.1994.1237

9. Lui, Z.; Thacker, S. G.; Fernandez-Castillejo, S.; Neufeld, E. B.; Ramaley, A. T.; Bittman, R. ChemBioChem 2014, 15, 2087-2096. doi:10.1002/cbic.201402042

10. Smith, B.; Land, H. Cell Rep. 2012, 2, 580-590. doi:10.1016/j.celrep.2012.08.011

11. Orefice, P.; Peterson, J.; Sun, B. Undergraduate Res. Posters 2014 Book 29.

12. Nie, Y.; Ji, L.; Ding, H.; Xie, L.; Li, L.; He, B.; Wu, Y.; Gu, Z. Theranostics 2012, 2, 1092-1103. doi:10.7150/thno.4949

13. Apiratikul, N.; Penglong, T.; Suksen, K.; Savati, S.; Chairoungdua, A.; Yingyongnarongkul, B. Russ. J. Bioorg. Chem. 2013, 39, 444-450. doi:10.1134/S1068162013030035

14. Bourbon, P.; Peng, Q.; Ferraudi, G.; Stauffacher, C.; Wiest, O.; Helquist, P. Bioorg. Med. Chem. Lett. 2013, 23, 2162-2165. doi:10.1016/j.bmcl.2013.01.095

15. de Medina, P.; Paillasse, M. R.; Segala, G.; Voisin, M.; Mhamdi, L.; Dalenc, F.; Lacroix-Triki, M.; Filleron, T.; Pont, F.; Al Saati, T.; Morisseau, C.; Hammock, B. D.; Silvente-Poirot, S.; Poirot, M. Nat. Commun. 2013, 4, No. 1840. doi:10.1038/ncomms2835

16. Higgins, C. D.; Koellhoffer, J. F.; Chandran, K.; Lai, J. R. Bioorg. Med. Chem. Lett. 2013, 23, 5356-5360. doi:10.1016/j.bmcl.2013.07.056 
17. Agarwal, S.; Schroeder, C.; Schlechtingen, G.; Braxmeier, T.; Jennings, G.; Knölker, H.-J. Bioorg. Med. Chem. Lett. 2013, 23, 5165-5169. doi:10.1016/j.bmcl.2013.07.015

18. Yang, C.; Shao, Y.; Zhi, X.; Huan, Q.; Yu, X.; Yao, X.; Xu, H. Bioorg. Med. Chem. Lett. 2013, 23, 4806-4812. doi:10.1016/j.bmcl.2013.06.099

19. Malaekeh-Nikouei, B.; Malaekeh-Nikouei, M.; Oskuee, R. K.; Ramezani, M. Nanomed.: Nanotech. Biol. Med. 2009, 5, 457-462. doi:10.1016/j.nano.2009.02.001

20. Lee, H. J.; Korshavn, K. J.; Kochi, A.; Derrick, J. S.; Lim, M. H. Chem. Soc. Rev. 2014, 43, 6672-6682. doi:10.1039/C4CS00005F

21. Schimmel, J.; Passos Eleutério, M. I.; Ritter, G.; Schmidt, R. R. Eur. J. Org. Chem. 2006, 1701-1721. doi:10.1002/ejoc.200500816

22. Svobodová, H.; Noponen, V.; Kolehmainen, E.; Sievänen, E. RSC Adv. 2012, 2, 4985-5007. doi:10.1039/c2ra01343f

23. Liu, W.; Liu, W.-L.; Liu, C.-M.; Liu, J.-H.; Yang, S.-B.; Zheng, H.-J.; Lei, H.-W.; Ruan, R.; Li, T.; Tu, Z.-C.; Song, X.-Y. Nutrition 2011, 27 , 700-706. doi:10.1016/j.nut.2010.06.010

24. Aly, M. R. E.; Saad, H. A.; Mohamed, M. A. M. Bioorg. Med. Chem. Lett. 2015, 25, 2824-2830. doi:10.1016/j.bmcl.2015.04.096 See for compounds $\mathbf{9}$ and $\mathbf{3 5}$.

25. Aly, M. R. E.; Ibrahim, E. I.; El Shahed, F. A.; Soliman, H. A.; Ibrahim, Z. S.; El-Shazly, S. A. M. Russ. J. Bioorg. Chem. 2012, 38 , 428-434. doi:10.1134/S1068162012030119

26. Aly, M. R. E.; Fodah, H. H. A. E. R.; Saleh, S. Y. Eur. J. Med. Chem. 2014, 76, 517-530. doi:10.1016/j.ejmech.2014.02.021

27. Eblen, D. R.; Annous, B. A.; Sapers, G. M. J. Food Prot. 2005, 68, 282-291.

28. Stenholm, T.; Hakanen, A. J.; Vaarno, J.; Pihlasalo, S.; Terho, P.; Hänninen, P. E.; Vuopio-Varkila, J.; Huovinen, P.; Kotilainen, P. Antimicrob. Agents Chemother. 2009, 53, 5088-5094. doi:10.1128/AAC.00518-09

29. Hedayati, M. T.; Pasqualotto, A. C.; Warn, P. A.; Bowyer, P.; Denning, D. W. Microbiology 2007, 153, 1677-1692. doi:10.1099/mic.0.2007/007641-0

30. Lossinsky, A. S.; Jong, A.; Fiala, M.; Mukhtar, M.; Buttle, K. F.; Ingram, M. Histol. Histopathol. 2006, 21, 1029-1041.

31. Tai, S.; Sun, Y.; Squires, J. M.; Zhang, H.; Oh, W. K.; Liang, C.-Z.; Huang, J. Prostate 2011, 71, 1668-1679. doi:10.1002/pros.21383

32. Appel, R. Angew. Chem., Int. Ed. Engl. 1975, 14, 801-811. doi:10.1002/anie.197508011

33. Sun, Q.; Cai, S.; Peterson, B. R. Org. Lett. 2009, 11, 567-570. doi:10.1021/ol802343z

34. Xu, W.; Luo, B. H.; Li, C. R.; Yang, J.; Zhou, C. R. Adv. Mater. Res. 2013, 647, 499-503. doi:10.4028/www.scientific.net/AMR.647.499

35. Rostovtsev, V. V.; Green, L. G.; Fokin, V. V.; Sharpless, K. B. Angew. Chem., Int. Ed. 2002, 41, 2596-2599. doi:10.1002/1521-3773(20020715)41:14<2596::AID-ANIE2596>3.0.CO ;2-4

36. Naeimi, H.; Nejadshafiee, V. New J. Chem. 2014, 38, 5429-5435. doi:10.1039/C4NJ00909F

37. El Ashry, E. S. H.; Aly, M. R. E. Pure Appl. Chem. 2007, 79, 2229-2242. doi:10.1351/pac200779122229

38. Bartolmäs, T.; Heyn, T.; Mickeleit, M.; Fischer, A.; Reutter, W.; Danker, K. J. Med. Chem. 2005, 48, 6750-6755. doi:10.1021/jm050558n
39. Aly, M. R. E.; Castro-Palomino, J.; Ibrahim, E.-S. I.; El-Ashry, E.-S. H.; Schmidt, R. R. Eur. J. Org. Chem. 1998, 2305-2316. doi:10.1002/(SICI)1099-0690(199811)1998:11<2305::AID-EJOC2305> 3.3.CO;2-N

40. Zemplén, G. Chem. Ber. 1926, 59, 2402-2413. doi:10.1002/cber.19260590938

41. Armitt, D. J.; Banwell, M. G.; Freeman, C.; Parish, C. R. J. Chem. Soc., Perkin Trans. 1 2002, 1743-1745. doi:10.1039/b205690a

42. Tejler, J.; Tullberg, E.; Frejd, T.; Leffler, H.; Nilsson, U. J. Carbohydr. Res. 2006, 341, 1353-1362. doi:10.1016/j.carres.2006.04.028

43. Stannard, K. A.; Collins, P. M.; Ito, K.; Sullivan, E. M.; Scott, S. A.; Gabutero, E.; Grice, I. D.; Low, P.; Nilsson, U. J.; Leffler, H.; Blanchard, H.; Ralph, S. J. Cancer Lett. 2010, 299, 95-110. doi:10.1016/j.canlet.2010.08.005

44. Strecker, G.; Wieruszeski, J.-M.; Michalski, J.-C.; Montreuil, J. Glycoconjugate J. 1989, 6, 67-83. doi:10.1007/BF01047891 See for the synthesis of compound 25.

45. Greilich, U.; Brescello, R.; Jung, K.-H.; Schmidt, R. R. Justus Liebigs Ann. Chem. 1996, 663-672.

See for the synthesis of compounds 29 and 33.

46. Zhou, Y.; Li, J.; Zhan, Y.; Pei, Z.; Dong, H. Tetrahedron 2013, 69, 2693-2700. doi:10.1016/j.tet.2013.02.024 See for the mechanism of organotin-mediated carbohydrate alkylation.

47. Bauer, A. M.; Kirby, W. M.; Sherris, C.; Turck, M. A. J. Clin. Pathol. 1966, 45, 493-496.

48. Skehan, P.; Storeng, R.; Scudiero, D.; Monks, A.; McMahon, J. J.; Vistica, D.; Warren, J. T.; Bokesch, H.; Kenney, S.; Boyd, M. R. J. Natl. Cancer Inst. 1990, 82, 1107-1112. doi:10.1093/jnci/82.13.1107

\section{License and Terms}

This is an Open Access article under the terms of the Creative Commons Attribution License

(http://creativecommons.org/licenses/by/2.0), which permits unrestricted use, distribution, and reproduction in any medium, provided the original work is properly cited.

The license is subject to the Beilstein Journal of Organic Chemistry terms and conditions:

(http://www.beilstein-journals.org/bjoc)

The definitive version of this article is the electronic one which can be found at: doi:10.3762/bjoc. 11.208 